\title{
Pengembangan modul bimbingan pribadi sosial untuk meningkatkan resiliensi Siswa Korban Bullying
}

\author{
Seri Ahmad \\ Bimbingan dan Konseling-SMA Negeri 1 Tongkuno \\ Emaill: seri.ahmad1985@gmail.com
}

(Diterima: 20-April-2017; di revisi: 26-Mei-2017; dipublikasikan: 29-Juni-2017)

\begin{abstract}
The objectives of the research are: (1) To discover the description of resilienciesof bullying victims and implementation of social personal guidance, (2) To develop social personal guidance module which is valid, interesting, and practical to improve resiliencies of the students as bullying victims (3) To develop social personal guidance module in improving resiliencies of the students as bullying victims. The study is Research and Development approach or Borg \& Gall development model wich had been modified with data collection techniques conducted through questionnaire, scale, and (FGD). The results of the research reveal that (1) Bullying behaviors are still often discovered, it shows that there are many students who were unable to escape from the unfortunate situation, so social personal guidance module to improve resiliencies of the students as bullying victims is very needed in school, (2) The module produced is valid, interesting, and practical based on the assessment conducted by two of Guidance Counseling experts. (3) The implementation of social personal guidance module can improve resiliencies of the students as bullying victims.
\end{abstract}

Keywords: Social Personal Guidance; Resilience; Bullying Victims.

Abstrak: Tujuan penelitian adalah (1) Mengetahui gambaran resiliensi korban bullying dan pelaksanaan bimbingan pribadi sosial. (2) Mengembangkan modul layanan bimbingan pribadi sosial yang valid, menarik, dan praktis untuk meningkatkan resiliensi siswa korban bullying. (3) Mengembangkan modul bimbingan pribadi sosial yang dapat meningkatkan resiliensi siswa korban bullying. Penelitian ini menggunakan pendekatan penelitian dan pengembangan $R \& D$ atau penelitian pengembangan model Borg \& Gall yang telah dimodifikasi, dengan teknik pengumpulan data melalui angket, skala, dan (FGD). Hasil penelitian menunjukkan bahwa (1) Perilaku bullying masih sering terjadi, ini terlihat dari masih banyaknya siswa yang tidak mampu untuk keluar dari situasi negatif tersebut, sehingga modul bimbingan pribadi sosial untuk meningkatkan resiliensi siswa sangat dibutuhkan di sekolah. (2) Modul yang dihasilkan telah valid, menarik dan praktis dari hasil penilaian yang dilakukan oleh dua orang ahli BK. (3) Penerapan modul bimbingan pribadi sosial dapat meningkatkan resiliensi siswa korban bullying.

Kata Kunci: Bimbingan Pribadi Sosial, Resiliensi, Korban Bullying

Copyright (C) 2017 Universitas Negeri Makassar.. This is an open access article under the CC BYNC-ND license (http://creativecommons.org/licenses/by-nc-nd/4.0/). 


\section{PENDAHULUAN}

Budaya bullying (kekerasan) atas nama senioritas masih terus terjadi dikalangan peserta didik. Karena meresahkan, pemerintah didesak segera menangani masalah ini secara serius. Bullying adalah suatu bentuk kekerasan anak (child abuse) yang dilakukan teman sebaya kepada seseorang (anak) yang lebih 'rendah' atau lebih lemah untuk mendapatkan keuntungan atau kepuasan tertentu.

(Olweus, 1995 dalam Sari \& Agung 2015: 32) men-deskripsikan bullying sebagai suatu perilaku yang disengaja terjadi berulangulang dan adanya penyalah-gunaan kekuasaan dari pelaku. Siswa yang mendapatkan perilaku tersebut umumnya tidak memiliki keberanian untuk melawan temannya yang lebih kuat sehingga mereka lebih banyak diam ketika dijahili, diejek, atau ketika mendapat kekerasan dari temannya (Coloroso, 2007 dalam Sari \& Agung 2015: 32).

Menurut data yang dilansir dari Komisi Perlindungan Anak Indonesia (KPAI) bahwa saat ini kasus bullying menduduki peringkat teratas pengaduan masyarakat. Dari 2011 hingga agustus 2014, KPAI mencatat 369 pengaduan terkait masalah tersebut. Jumlah itu sekitar 25\% dari total pengaduan di bidang pendidikan sebanyak 1.480 kasus. Bullying yang disebut KPAI sebagai bentuk kekerasan di sekolah, mengalahkan tawuran pelajar, diskriminasi pendidikan, ataupun aduan pungutan liar (Komisi Perlindungan Anak Indonesia, 2014).

Siswa SMK Negeri 2 Kendari terdiri dari berbagai macam latar belakang kehidupan yang berpotensi menimbulkan kejadian bullying. Berdasarkan hasil wawancara dengan guru BK ditemukan bahwa bullying merupakan sebuah kasus yang sering terjadi. Berdasarkan buku catatan kasus sejak 2012 sampai pertengahan 2015, kejadian bullying di sekolah ini sebanyak 87 kasus, seperti mengejek, memanggil teman dengan nama hewan, memberi label kepada teman, memalak, sampai pada kasus pemukulan. Pelanggaran ini merupakan pelanggaran terbanyak kedua selain kasus pelanggaran tata tertib.

Bullying yang sering terjadi adalah umpatan verbal seperti caci-maki, menghina teman, mengancam, memalak, dan ada pula kasus pemukulan. Adapun korban sasaran bullying tidak memandang jenis kelamin, status sosial, maupun tingkatan kelas. Korban bullying ada yang mampu bertahan dan pulih secara efektif namun ada pula individu yang gagal karena tidak berhasil keluar dari situasi yang tidak menguntungkan. Di SMK Negeri 2 Kendari, seringkali ditemukan korban bullying yang tidak mampu untuk keluar dari situasi yang tidak menguntungkan tersebut. Siswa yang menjadi korban cenderung menjadi malas masuk ke sekolah, sering bolos, tidak mampu beradaptasi sebagaimana sebelum menjadi korban, tidak mampu menonjolkan kembali potensi diri, cenderung takut bila akan berhadapan dengan pelaku bullying, takut pulang sendiri, dan memilih untuk lebih banyak menyendiri. Menurut Ida dan Komang (2014), dalam penelitiannya, terhadap 176 anak sekolah di Bali, korban "bullying" akan mengalami kesulitan dalam bergaul, merasa takut datang ke sekolah sehingga absensi mereka tinggi dan tertinggal pelajaran, dan mengalami kesulitan berkonsentrasi sehingga akan berdampak pada prestasi belajarnya. (Glew, dkk, 2005 dalam Wahyuni \& Asra 2014: 2) menemukan bahwa siswa yang menjadi korban bullying memiliki prestasi akademik yang rendah, merasa tidak aman di sekolah, merasa tidak memiliki sekolahnya, dan merasa sedih, dibandingkan siswa yang tidak menjadi korban bullying.

Ketidaksanggupan untuk bangkit dari situasi tidak mengenakkan yang pernah diperoleh korban bullying merupakan sebuah masalah yang perlu ditangani secara serius di samping kasus-kasus lain yang terjadi di SMK Negeri 2 Kendari. Melalui sentuhan BK, maka diharapkan siswa mampu bangkit atas keterpurukan yang dialaminya. Adapun fenomena dimana individu mampu untuk keluar dari situasi negatif, sehingga ia dapat bangkit dan pulih kembali dikenal dengan istilah resiliensi oleh Tugade \& Fredrikson (Tatyagita \& Handayani 2014: 17).

Resiliensi berarti kemampuan untuk pulih kembali dari suatu keadaan, kembali ke bentuk semula setelah dibengkokkan, ditekan, atau diregangkan. Secara sederhana resiliensi adalah kemampuan individu untuk bangkit kembali dari kondisi terpuruk. Terdapat tiga sumber resiliensi, yaitu I have, I am dan I can. Resiliensi dapat ditingkatkan ketika dukungan diberikan (I have), ketika kekuatan dari dalam diri seperti kepercayaan diri, sikap yang optimis, sikap untuk menghargai dan empati dikembangkan ( $\mathrm{I}$ am) dan ketika kemampuan interpersonal dan memecahkan masalah 
diperoleh (Grotberg, 2005 dalam Tatyagita \& Muryantinah 2014: 18).

Sekolah sebagai lingkungan kritis memang sangat strategis untuk membangun resiliensi siswa. Menurut (Benard dalam Prihastuti 2011) kondisi lingkungan yang perlu diperhatikan pendidik dalam membangun resiliensi siswa, yaitu provide caring and support (memberikan perhatian \& dukungan), set and communicate high expectations (menetapkan \& mengkomunikasikan harapanharapan yang tinggi tapi realistik, sehingga dapat menjadi motivator yang efektif), dan provide opportunities for meaningful participation (memberikan kesempatan untuk patisipasi yang bermakna).

Upaya-upaya yang dilakukan oleh guru

BK di SMK Negeri 2 Kendari untuk meningkatkan resiliensi bagi korban bullying adalah melalui mediasi, pemberian nasihat, serta konseling individu. Akan tetapi hal ini tidak mampu memberikan hasil optimal, kasus bullying masih sering terjadi dan korban bullying masih kurang mampu untuk keluar dari situasi yang tidak mengenakkan tersebut. Dibutuhkan suatu inovasi bagi guru BK untuk dapat melakukan layanan bagi korban bullying. Salah satu upaya yang dapat dilakukan adalah dengan mengoptimalkan kembali pelaksanaan bimbingan pribadi sosial pada korban bullying. Yusuf \& Nurihsan (2012: 11), menyatakan bahwa bimbingan sosial pribadi adalah bimbingan untuk membantu para individu dalam memecahkan masalah-masalah sosial pribadi.

Berdasarkan hasil wawancara dengan koordinator BK mengenai upaya peningkatan resiliensi ditemukan bahwa salah satu permasalahan yang dimiliki oleh guru BK adalah kurangnya materi serta pedoman dalam bentuk modul untuk mengoperasionalkan bimbingan pribadi sosial. Tidak terdapat modul-modul yang dapat digunakan sebagai pedoman untuk menjalankan bimbingan pribadi sosial kepada siswa. Hal ini diperkuat lagi dengan fakta bahwa hal-hal yang berkaitan dengan upaya pengembangan resiliensi korban bullying merupakan suatu hal yang masih bersifat baru.

Berdasarkan fenomena di atas, maka perlu adanya sebuah inovasi dalam praktik pelayanan BK sebagai upaya dalam meningkatkan resiliensi bagi siswa korban bullying. Upaya tersebut dapat ditempuh melalui pengembangan modul bimbingan pribadi sosial untuk meningkatkan resiliensi siswa korban bullying. Selain itu, berdasarkan hasil studi literatur ditemukan bahwa melalui pengembangan modul bimbingan pribadi sosial dapat memberikan kontribusi bagi guru BK yang dapat digunakan untuk membantu konseli/siswa dalam mengatasi permasalahan yang dihadapinya terutama terhadap korban bullying. Hal ini sesuai dengan pendapat (Prayitno 2009: 26 dalam Yandri, dkk, 2013: 98) yang menyatakan bahwa "pelayanan konseling tertuju kepada kondisi pribadi yang mandiri, sukses dan berkehidupan efektif dalam kesehariannya". Berdasarkan kajian literatur yang dilakukan pula ditemukan bahwa modul bimbingan sosial mengandung aspek yang dapat dikembangkan dalam bentuk panduan pelaksanaan konseling bagi siswa.

\section{METODE}

Jenis penelitian ini adalah penelitian dan pengembangan (research and development). Sugiyono (2012: 407) metode penelitian dan pengembangan adalah metode penelitian yang digunakan untuk menghasilkan produk tertentu dan menguji keefektifan produk tersebut. Model pengembangan yang dilakukan dalam penelitian ini adalah model pengembangan prosedural. Model prosedural merupakan model deskriptif yang menggambarkan alur atau langkah-langkah prosedural yang harus diikuti untuk menghasilkan suatu produk tertentu (Setyosari, 2013: 230. Aryani,2014).

Model pengembangan ini mengacu pada strategi pengembangan yang dikemukakan oleh Borg and Gall (Mulyataningsih, 2014: 163-165) yang terdiri dari 10 tahapan umum, yaitu: 1) Riset awal dan pengumpumpulan informasi, 2) Perencanaan, 3) Penyusunan format model awal, 4) Melakukan uji coba tahap awal, 5) Melakukan revisi model utama, 6) Melakukan uji coba lapangan model utama, 7) Melakukan revisi model operasioanal, 8) Melakukan uji model operasional, 9) Melakukan revisi model, 10).Mendesiminasikan dan mengimplementasikan produk .

Adapun teknik pengumpulan data yang digunakan adalah angket, skala dan Focuss Grup Discussion (FGD). Teknik analisis data yang digunakan untuk mengolah data penelitian ini adalah dengan menggunakan analisis deskriptif.

\section{HASIL DAN PEMBAHASAN}


Penelitian Awal dan Pengumpulan Informasi. Adapun aspek-aspek yang dikaji melalui bagian ini meliputi:

a) Karakteristik resiliensi siswa. Berdasarkan hasil wawancara dengan koordinator BK SMK Negeri 2 Kendari diperoleh informasi bahwa kasus bullying sering terjadi.

Berdasarkan wawancara dengan salah seorang korban bullying diperoleh informasi tambahan bahwa perilaku bullying yang sering terjadi adalah umpatan verbal seperti cacimaki, menghina teman, mengancam, memalak, dan ada pula kasus pemukulan. Hal ini kemudian menimbulkan efek ketakutan bagi korban sehingga korban memutuskan untuk tidak ke sekolah, pulang lebih cepat tanpa izin dari guru (membolos), atau pun berpura-pura sakit agar diizinkan untuk pulang lebih awal. Kondisi ini secara tidak langsung menggambarkan bahwa resiliensi siswa rendah sehingga siswa membutuhkan jalan keluar untuk mengentaskan permasalahan tersebut.

Berdasarkan hasil wawancara dengan guru BK lain adalah dari sekian banyak korban bullying ada yang mampu bertahan dan pulih secara efektif namun ada pula individu yang gagal.

Melihat hasil wawancara diatas maka semua siswa pun berpotensi menjadi korban bullying sehingga perlu penanganan khusus yang dilakukan perlu diberikan kepada semua siswa. Penanganan tersebut diupayakan agar semua siswa mampu bangkit dari situasi buruk setelah menjadi korban bullying.

b) Strategi pelaksanaan BK pribadi sosial di Sekolah. Bidang kehidupan pribadi sosial merupakan bidang pengembangan kehidupan dalam BK yang penting untuk dikembangkan di samping bidang lain seperti belajar dan karir. Bidang pribadi sosial akan mengarahkan siswa agar mampu hidup secara efektif dengan masyarakat luas.

Adapun materi layanan yang diberikan didominasi tentang bagaimana cara bergaul dengan efektif atau etika dalam bergaul. Untuk konseling individual, konseling kelompok, dan bimbingan kelompok dilakukan secara insidental. Strategi ini dilakukan secara terjadwal karena di SMK Negeri 2 Kendari BK telah dialokasikan waktu untuk tatap muka didalam kelas walaupun hanya diberikan waktu satu jam pelajaran.

Pelaksanaan layanan informasi dan penguasaan konten yang menjadi tulang punggung strategi BK pribadi sosial di SMK
Negeri 2 Kendari tersebut pada dasarnya bersifat baik. Strategi tersebut ditujukan untuk memberikan pemahaman mengenai bagaimana cara hidup dan bergaul secara efektif bagi siswa. Namun jika dicermati pada dasarnya siswa merupakan individu yang khas dan unik serta memiliki permasalahan yang bervariasi. Olehnya itu proporsi layanan BK pribadi sosial di sekolah harus diseimbangkan dengan layanan-layanan BK lainnya agar kebutuhan siswa sebagai sasaran layanan terlayani secara optimal.

c) Kajian tentang tingkat kebutuhan modul. Telah diuraikan sebelumnya bahwa BK pribadi sosial di SMK Negeri 2 Kendari secara dominan diselenggarakan melalui layanan informasi dan penguasaan konten. Kedua bentuk layanan tersebut diselenggarakan secara terjadwal di dalam kelas. Adapun layananlayanan lain diselenggarakan secara insidental sesuai dengan kondisi yang terjadi di lingkungan sekolah. Walaupun telah terjadwal dalam pelaksanaannya, namun ternyata hasil dari penyelenggaraan kegiatan layanan tersebut belum dapat terlihat secara optimal. Salah satu bukti pendukung pernyataan tersebut adalah adanya fakta bahwa korban bullying tidak mampu beresiliensi secara efektif.

Berdasarkan hasil penelusuran melalui wawancara kepada guru BK di sekolah ini diperoleh informasi bahwa salah satu kendala dalam penyelenggaraan BK pribadi sosial yang secara khusus berkaitan dengan kemampuan resiliensi adalah tidak adanya pedoman yang dapat digunakan oleh guru BK dalam mengoperasionalkan materi tentang resiliensi. Pedoman tersebut dianggap penting walaupun pada dasarnya guru BK di sekolah tersebut telah paham dengan apa yang dimaksud dengan resiliensi. Hal ini mengakibatkan pemahaman tersebut hanya menjadi sebatas sebuah konsep dan belum mampu dituangkan dalam pemberian layanan.

d) Kajian teoritik. Upaya pengkajian teoretik ditempuh melalui studi literatur. Studi literatur dilakukan melalui pengumpulan bahan mengenai modul bimbingan pribadi sosial untuk meningkatkan resiliensi. Bahan yang dikumpulkan yakni mengenai pengenalan terhadap resiliensi dan bagaimana cara mengadministrasikannya dalam layanan BK. Selain bahan tentang resiliensi, dikumpulkan pula bahan yang berkaitan dengan aspek bimbingan pribadi sosial khususnya berkaitan dengan bullying. Bahan diperoleh dari bacaan- 
bacaan yang termuat di buku baik itu buku cetak maupun buku elektronik, jurnal, prosiding, serta karya-karya ilmiah lain yang telah dipublikasikan sebelumnya.

Berdasarkan kajian pada literatur yang diperoleh, ditemukan bahwa upaya pengembangan modul bimbingan pribadi sosial untuk meningkatkan resiliensi siswa korban bullying merupakan salah satu upaya yang dapat dilakukan dalam membantu peningkatan resiliensi siswa.

Pengembangan produk. Pengembangan produk yang dimaksudkan merupakan hal-hal yang dipersiapkan untuk menyusun modul bimbingan pribadi sosial yaitu: jenis kegiatan pada tahap perencanaan, materi yang diprogramkan, tenaga yang dipersiapkan, serta sarana-prasarana yang diperlukan untuk kegiatan.

Setelah mempertimbangkan aspek-aspek tersebut maka langkah selanjutnya adalah pembuatan modul. Penyusunan modul bimbingan pribadi sosial untuk meningkatkan resiliensi siswa diawali dengan analisis kebutuhan yang telah diuraikan sebelumnya. Setelah diketahui apa saja kebutuhan yang diperlukan oleh siswa terkait dengan pengembangan resiliensi siswa, kemudian disusun materi sesuai dengan kebutuhankebutuhan yang terkait dengan modul bimbingan pribadi sosial untuk meningkatkan resiliensi siswa korban bullying. Rumusan materi disusun berdasarkan masalah yang dialami oleh siswa. Adapun materi-materi pada modul bimbingan pribadi sosial untuk meningkatkan resiliensi siswa dikembangkan dari kebutuhan-kebutuhan siswa adalah sebagai berikut: Apakah bullying itu?, Kenalilah dirimu, Percaya pada diri sendiri, Belajar berkata tidak, serta Menghadapi dan melaporkan pelaku bully.

Validasi Ahli. Model hipotetik atau draf modul yang telah dirancang selanjutnya melalui tahap penilaian atau validasi dari ahli yang kompeten di bidang BK. Tujuan penilaian ini adalah untuk mengetahui kelayakan konstruk dan empirik pada produk yang telah dirancang sebelum diimplementasikan. Uji kesahihan/ kevalidan dilakukan dalam dua bentuk, yaitu kesahihan konstruk dilakukan oleh dua orang ahli BK. Sementara itu, uji kesahihan empiris dilakukan dengan melibatkan calon pengguna modul yakni guru BK.

Uji kesahihan konstruk dilakukan untuk mengetahui sejauh mana tingkat kesahihan konstruk modul yang dikembangkan.

Aspek yang dinilai dalam menguji kesahihan konstruk produk yaitu pada aspek kegunaan, kelayakan, ketepatan, dan isi materi.

Untuk setiap aspek diperoleh skor 24 pada aspek kegunaan, skor 20 pada aspek kelayakan, 19,5 pada aspek ketepatan serta skor 16,5 pada isi materi.

Tabel 1. Hasil pengujian kesahihan konstruk

\begin{tabular}{clcccc}
\hline \multirow{2}{*}{ No. } & \multirow{2}{*}{ Aspek yang Dinilai } & \multicolumn{2}{c}{$\begin{array}{c}\text { Perolehan Skor Dari } \\
\text { Ahli }\end{array}$} & \multirow{2}{*}{$\begin{array}{c}\text { Rerata } \\
\text { Sko/r }\end{array}$} & Kategori Penilaian*) \\
\cline { 3 - 4 } & & Ahli 1 & Ahli 2 & & \\
\hline 1. & Kegunaan (utility) & 25 & 23 & 24 & Sangat berfaedah \\
2. & Kelayakan (feasibility) & 22 & 18 & 20 & Sangat layak \\
3. & Ketepatan (accuracy) & 21 & 18 & 19,5 & Sangat tepat \\
4. & Isi materi (content) & 18 & 15 & 16,5 & Sangat layak \\
\hline
\end{tabular}

Hasil pengujian kesahihan konstruk produk dilakukan oleh dua ahli BK yaitu Dr. $\mathrm{Hj}$. Kustiah Sunarty, M.Pd., dan Dr. Farida Aryani, M.Pd. Adapun masukan yang diberikan oleh validator yakni gambar sebaiknya original, langkah-langkah harus operasional dan mudah dipahami siswa, petunjuk harus jelas, metode dalam pelatihan harus lebih inovatif dan kreatif, serta bahasa jangan terlalu teoretis, buat lebih praktis. Masukan yang diberikan olehvalidator tersebut selanjutnya menjadi bahan revisi bagi pengembangan modul sebelum dilakukan uji kesahihan empiris. Revisi dilakukan dalam rangka memperbaiki hal-hal yang terdapat di dalam modul yang perlu dibenahi dan dikembangkan lagi.

Uji kesahihan empiris dilakukan untuk memperoleh masukan dari pihak yang akan menjadi pengguna model, yakni guru BK. Teknik uji kesahihan empiris dilakukan melalui angket terbuka dan Focus Group Discussion (FGD).

Angket terbuka. Angket diberikan setelah dilakukan distribusi atau penyebaran modul kepada empat orang guru BK dengan 
tujuan memberikan respon terhadap keberadaan modul yang dikembangkan.

Respon-respon yang diberikan oleh praktisi menyiratkan bahwa upaya pengembangan modul bimbingan pribadi sosial untuk meningkatkan resiliensi siswa korban bullying merupakan sebuah inovasi baru dan memiliki unsur kemenarikan dalam praktik pelayanan BK di sekolah.

Kehadiran modul bimbingan pribadi sosial untuk meningkatkan resiliensi siswa korban bullying dianggap memberikan pengaruh yang positif bagi pelaksanaan program BK di sekolah.

Kemungkinan penerapan modul bimbingan pribadi sosial untuk meningkatkan resiliensi siswa korban bullying begitu besar untuk dilakukan

Focuss Grup Discussion (FGD). FGD digunakan untuk mendapatkan penilaian dari guru BK berkenaan dengan konstruk modul agar mencapai hasil yang baik.

Berdasarkan hasil pelaksanaan FGD diketahui bahwa produk berupa modul bimbingan pribadi sosial untuk meningkatkan resiliensi siswa korban bullying dapat dipahami dan dilaksanakan oleh guru BK. Namun demikian pada beberapa bagian perlu lebih disempurnakan, baik berkenaan dengan isi maupun bahasa. Kenyataan ini juga ditunjukkan oleh skor penilaian peserta FGD yang secara keseluruhan memperoleh skor rata-rata 57,5 dari skor ideal sebesar 64. Hal ini dapat dimaknai bahwa produk yang telah dikembangkan berada dalam kategori sangat baik.

Untuk mengetahui kesahihan konstruk dan kesahihan empirik melalui angket terbuka dan FGD diperoleh masukan-masukan demi perbaikan produk. Selanjutnya, masukanmasukan validator terhadap produk menjadi bahan revisi produk. Hal-hal yang menjadi inti

Tabel. 2. Data Tingkat Resiliensi Sebelum (Pretest) dan Setelah (Posttest) Diberi Modul Bimbingan Sosial

\begin{tabular}{|c|c|c|c|c|c|}
\hline \multirow[b]{2}{*}{ Interval } & \multirow[b]{2}{*}{ Kategorisasi } & \multicolumn{2}{|c|}{ Pretest } & \multicolumn{2}{|c|}{ Posttest } \\
\hline & & Frekuensi & $\begin{array}{c}\text { Persentase } \\
(\%)\end{array}$ & Frekuensi & Persentase (\%) \\
\hline$\geq 140$ & Sangat Tinggi & 0 & 0 & 1 & 12,5 \\
\hline $121-139$ & Tinggi & 0 & 0 & 5 & 62,5 \\
\hline $102-120$ & Sedang & 1 & 12,5 & 2 & 25 \\
\hline $83-101$ & Rendah & 4 & 50 & 0 & 0 \\
\hline$<82$ & Sangat Rendah & 3 & 37,5 & 0 & 0 \\
\hline \multicolumn{2}{|c|}{ Jumlah } & 8 & 100 & 8 & 100 \\
\hline
\end{tabular}

revisi produk difokuskan pada komponen atau aspek yang termuat dalam produk.

Adapun revisi yang dilakukan adalah revisi terhadap modul bimbingan pribadi sosial yang sedang dikembangkan sebagai berikut.

Langkah-langkah harus operasional dan mudah dipahami anak. Berdasarkan saran yang diberikan, maka peneliti telah memperbaiki langkah-langkah operasional modul agar lebih mudah dipahami anak. Peneliti memaknai penggunaan bahasa yang lebih mudah dipahami anak dengan penggunaan bahasa yang sesuai dengan tingkat usia dan tahap perkembangan siswa.

Petunjuk atau panduan penggunaan modul harus jelas. Sesuai dari saran ahli tersebut, maka peneliti telah memperbaiki dan menyusun petunjuk atau panduan penggunaan modul.

Metode dalam pelatihan harus lebih inovatif dan kreatif. Berdasarkan masukan tersebut, peneliti telah merubah langkah-langkah pembelajaran yang terdapat dalam modul agar pemberian layanan yang dilakukan menjadi lebih aktif dan terpusat pada siswa.

Bahasa jangan terlalu teoretis, buat lebih praktis. Peneliti telah merevisi beberapa pembahasan materi dengan menggunakan bahasa yang lebih teknik dan penjelasan-penjelasan praktis pada setiap sesi.

Uji Kelompok Kecil. Uji coba produk dilakukan pada kelompok kecil yaitu 8 siswa.

Siswa diberikan perlakuan berupa kegiatan layanan informasi dan penguasaan konten secara klasikal dan penilaian umum berupa pengisian lembar kerja dalam setiap pertemuan untuk mengetahui pemahaman siswa terhadap pelaksanaan modul bimbingan pribadi sosial untuk meningkatkan resiliensi siswa korban bullying. 
Berdasarkan data diperoleh bahwa tingkat resiliensi siswa sebelum diberi modul bimbingan pribadi sosial adalah terdapat 3 siswa $(37,5 \%)$ berada pada kategori sangat rendah, 4 siswa $(50 \%)$ berada pada kategori rendah, 1 siswa $(12,5 \%)$ berada pada kategori sedang, dan tidak terdapat siswa (0\%) yang berada pada kategori tinggi dan sangat tinggi. Namun setelah diberikan modul bimbingan pribadi sosial, maka terjadi peningkatan tingkat resiliensi.

Berdasarkan data diatas, setelah diberikan modul bimbingan pribadi sosial maka tidak terdapat siswa (0\%) yang tingkat resiliensinya pada kategori sangat rendah dan rendah, 2 siswa (25\%) tingkat resiliensinya pada kategori sedang, 5 siswa $(62,5 \%)$ tingkat resiliensinya pada kategori

tinggi, dan 1 siswa (12,5\%) tingkat resiliensinya pada kategori sangat tinggi.

Revisi II. Revisi kedua dilakukan berdasarkan data hasil uji kelompok kecil yang telah dilakukan sebanyak lima tahap kegiatan pelaksanaan. Adapun proses pelaksanaan dari kelima tahap kegiatan yang telah dilakukan oleh peneliti dalam uji kelompok kecil meliputi tahap persiapan, penyampaian, pelatihan dan penilaian atau evaluasi. Hasil data yang masuk dijadikan sebagai bahan analisa dalam melakukan revisi kedua modul bimbingan pribadi sosial untuk meningkatkan resiliensi siswa korban bullying.

Modul Akhir Bimbingan pribadi sosial. Pada tahap ini, modul bimbingan pribadi sosial untuk meningkatkan resiliensi siswa korban bullying telah mampu mencapai tahap akhir dimana modul bimbingan pribadi sosial yang disusun sudah dapat digunakan sebagai panduan bagi guru BK di sekolah. Setelah melaksanakan tahapan-tahapan penelitian di atas, maka lahirlah modul bimbingan pribadi sosial untuk meningkatkan resiliensi siswa korban bullying yang telah diuji oleh ahli serta diuji melalui uji kelompok kecil yang terbukti memberikan perubahan secara signifikan yaitu dapat meningkatkan resiliensi siswa korban bullying di SMK Negeri 2 Kendari.

\section{SIMPULAN DAN SARAN}

Perilaku bullying di SMK Negeri 2 Kendari masih sering terjadi, ini terlihat dari masih banyaknya siswa yang tidak mampu untuk keluar dari situasi yang tidak menguntungkan tersebut, sehingga modul bimbingan pribadi sosial untuk meningkatkan resiliensi siswa korban bullying sangat dibutuhkan di sekolah.

Modul yang dihasilkan telah valid, menarik dan praktis dari hasil penilaian terhadap kegunaan, kelayakan, dan ketepatan yang dilakukan oleh dua orang ahli BK.

Penerapan modul bimbingan pribadi sosial dapat meningkatkan resiliensi siswa korban bullying di SMK Negeri 2 Kendari.

Berikut ini merupakan beberapa saran terkait produk yang dihasilkan : 1) Produk yang dikembangkan merupakan suatu hal yang baru bagi kalangan praktisi. Dengan demikian sekiranya produk penelitian ini perlu disosialisasikan kepada para guru BK melalui kegiatan-kegiatan ilmiah seperti seminar, talk show, workshop, pelatihan, serta simulasi di dalam kegiatan Musyawarah Guru Bimbingan dan Konseling (MGBK). 2) Modul yang dihasilkan tidak akan mampu terlaksana jika pihak sekolah tidak memberikan alokasi waktu bagi pelayanan BK di dalam kelas. Dengan demikian diharapkan pihak sekolah mampu memberikan alokasi waktu yang cukup memadai bagi guru BK untuk melakukan kegiatan tatap muka di dalam kelas. 3) Dalam pelaksanaannya, modul yang dikembangkan diselenggarakan dalam situasi layanan informasi maupun layanan penguasaan konten. Untuk itu, agar dapat memperoleh hasil pelaksanaan yang optimal maka guru BK wajib untuk selalu mengasah keterampilan profesional dan pedagogisnya dalam pemberian layanan dari waktu ke waktu. Selain itu, karena penelitian ini hanya menghasilkan suatu produk, maka guru BK diharapkan untuk menerapkan produk yang dikembangkan dalam membantu siswa. 4) Prosedur penelitian ini telah dimodifikasi sampai tahap uji kelompok kecil saja. Olehnya itu, bagi peneliti yang ingin melanjutkan penelitian ini diharapkan mampu melakukan penelitian lanjutan terhadap pengembangan ini sampai pada tahap desiminasi produk serta perlu dilakukannya eksperimen lebih lanjut guna mengetahui efektivitas pemberian modul dalam meningkatkan resiliensi siswa.

\section{DAFTAR RUJUKAN}

Aryani, F. (2014). Model Character Development Training ( CDT ) Untuk Meningkatkan Perilaku. Jurnal Pendidikan Dan Pengajaran, 47(1), 21-28. 
Komisi Perlindungan Anak Indonesia. 2014. KPAI : Kasus Bullying dan Pendidikan Karakter, (Online), (http://www.kpai.go.id/berita/kpaikasus-bullying-dan-pendidikankarakter/, Diakses 24 Desember 2015).

Prihastuti, (2011). Profil Resiliensi Pendidik Berdasarkan Resilience Quetient Test. Fakultas Psikologi UNAIR: Jurnal Penelitian dan Evaluasi Pendidikan. 199-214.

Sari, R.N \& Agung, I.M (2015). Pemaafan dan Kecenderungan Perilaku Bullying pada Siswa Korban Bullying. Fakultas Psikologi Universitas Islam Negeri Sultan Syarif Kasim Riau: Jurnal Psikologi, 11(1), 32-36.

Setyosari, P. (2013). Metode Penelitian dan Pengembangan (Edisi Ketiga). Jakarta: Kencana.

Mulayataningsih, E. (2014). Metode Penelitian Terapan Bidang Pendidikan. Bandung: Alfabeta.

Tatyagita, R.R.S. \& Muryantinah M.H. (2014). Resiliensi Pada Remaja Korban Bullying. Fakultas Psikologi Universitas Airlangga: Jurnal Psikologi Kepribadian dan Sosial, 3(1), 15-22.

Yusuf, S. \& Nurihsan, J. (2009). Landasan Bimbingan dan Konseling. Bandung: PT Remaja Rosdakarya Offset.

Wahyuni. S \& Asra. Y.K (2014). Kecenderungan Anak Menjadi Pelaku dan Korban Bullying Ditinjau Dari Kualitas Kelekatan Dengan Ibu Yang Bekerja. Fakultas Psikologi UIN Suska Riau: Jurnal marwah, Vol. XIII, 1-20.

Yandri. H, Dkk. (2013). Pengembangan Modul Bimbingan Dan Konseling Untuk Pencegahan Bullying di Sekolah. Jurusan Bimbingan dan Konseling FIP UNP: Jurnal Jurnal Ilmiah Konseling. 2(1). 98-106. 